\title{
The relationship between blue swimming crab (Portunus pelagicus) abundance and environmental parameters in Spermonde Archipelago
}

\author{
Muh. Saleh Nurdin ${ }^{1 *}$, Eniwati ${ }^{2}$, Teuku Fadlon Haser ${ }^{3}$, Nur Hasanah ${ }^{1}$ \\ ${ }^{1}$ Faculty of Animal Husbandry and Fishery, Tadulako University, Indonesia. \\ 2Islamic Senior High School 2 Palu, Indonesia. \\ ${ }^{3}$ Faculty of Agriculture, Samudra University, Indonesia. \\ *Corresponding author: salehnurdin@untad.ac.id
}

\section{ARTICLE INFO}

\section{Keywords:}

Abundance; Blue swimming crab; Environmental Parameters; Spermonde Archipelago.

\section{How to cite:}

Nurdin, M. S., Eniawati., Haser, T. F., \& Hasanah, N. (2020). The relationship between blue swimming crab (Portunus pelagicus) abundance and environmental paramaters in Spermonde Archipelago. Tomini Journal of Aquatic Science, 1(1), 8-15

\begin{abstract}
Management and conservation of the blue swimming crabs by the marine protected area method require the abundance and environmental parameter information of the blue swimming crab. The aim of this study is to analyze the changes in the relative abundance of the blue swimming crab and its environmental parameters. The study was conducted from March to July 2015, in the waters of Salemo Island, Spermonde Archipelago. The specimens were collected at the three fishing locations around the mangrove, seagrass, and coral reef ecosystems. The variable of relative abundance of the blue swimming crab is determined catch per effort. Samples of environmental parameters such as temperature and current speed are measured in situ. However, for the salinity, dissolved oxygen, ammonia, nitrate, plankton, and chlorophyll-a were analyzed in the laboratory. A comparison of the blue swimming crab abundance in each ecosystem was conducted by One Way ANOVA. Moreover, the relationship between blue swimming crab abundance with environmental parameters was analyzed by multiple regression. The results show that the blue swimming crab is abundant in the seagrass and coral reefs. The environmental parameter that significantly influences the abundance of the blue swimming crab is salinity. The suitable area for blue swimming carb protection based on abundances are seagrass and coral reef ecosystems.
\end{abstract}

\section{INTRODUCTION}

Blue swimming crab (Portunus pelagicus) is a crustacean that economically important that has been exported and has been highly preferred by consumers for food (Siang \& Nurdiana, 2015; Adam et al., 2016; Panggabean et al., 2018). As a consequence, many people have competed on its utilization, starting from the capturing cycle to marketing (Kusuma \& Dewi, 2017). Spermonde Islands are one of the spreading areas of Blue swimming crab in Indonesia with 
considerable resource potential. In the Spermonde Islands, blue swimming crab stocks are scattered in small islands such as the Salemo Island (Nurdin, 2015; Nurdin et al., 2016; Nurdin et al., 2018). In Spermonde Islands, blue swimming crab resources remain open for overexploitation by fishers. Over-exploitation of blue swimming crab can result in a decline in stock (Ernawati et al., 2015).

However, the blue swimming crab stock in the Spermonde Islands has overfished (Nurdin et al., 2015) and endangered its sustainability and continuity of utilization (Fudjaja et al., 2013; Ernawati et al., 2014). However, it is still able to survive due to blue swimming crab spawning in the Spermonde Islands that can occur throughout the year, and the release of eggs does not depend on the specific times (Nurdin et al., 2019a; Nurdin et al., 2019b). The effect of this productivity degree may allow the blue swimming crab to survive even under the stress of overfishing (Nurdin et al., 2015). If the crab is continually exploited without proper planning and sustainable capacity management, sooner or later, the blue swimming crab resources in the Spermonde Islands will face the risk of extinction. Therefore, the crab management and conservation strategy should be applied based on the area protection method.

Management and conservation of the blue swimming crabs by the area protection method requires the support of research information such as reproductive biology, population dynamics, and habitat. Because information about the population dynamics of blue swimming crab in their habitat, especially its abundance associated with the environmental parameters that have been affected, is still limited, information about the abundance of the blue swimming crab is very important in management to determine when and where to fish can be performed. Such information may increase the basic knowledge about the population dynamics of blue swimming $\mathrm{crab}$ as the core of consideration in management planning and conservation based on area protection.

\section{MATERIAL AND METHODS}

Study site. This study was conducted in five months (March-July 2015) at Salemo Islands, Spermonde Archipelago. Specimens were collected at the fishing ground of blue swimming crab around the mangrove, seagrass, and coral reef ecosystems. All samples were analyzed at the Laboratory of Aquatic Productivity, Faculty of Marine Science and Fisheries, Hasanuddin University. The collection of broodstock of blue swimming crab and environmental parameters were performed two times in a month when lifting a fishing gear (hauling) (Figure 1).

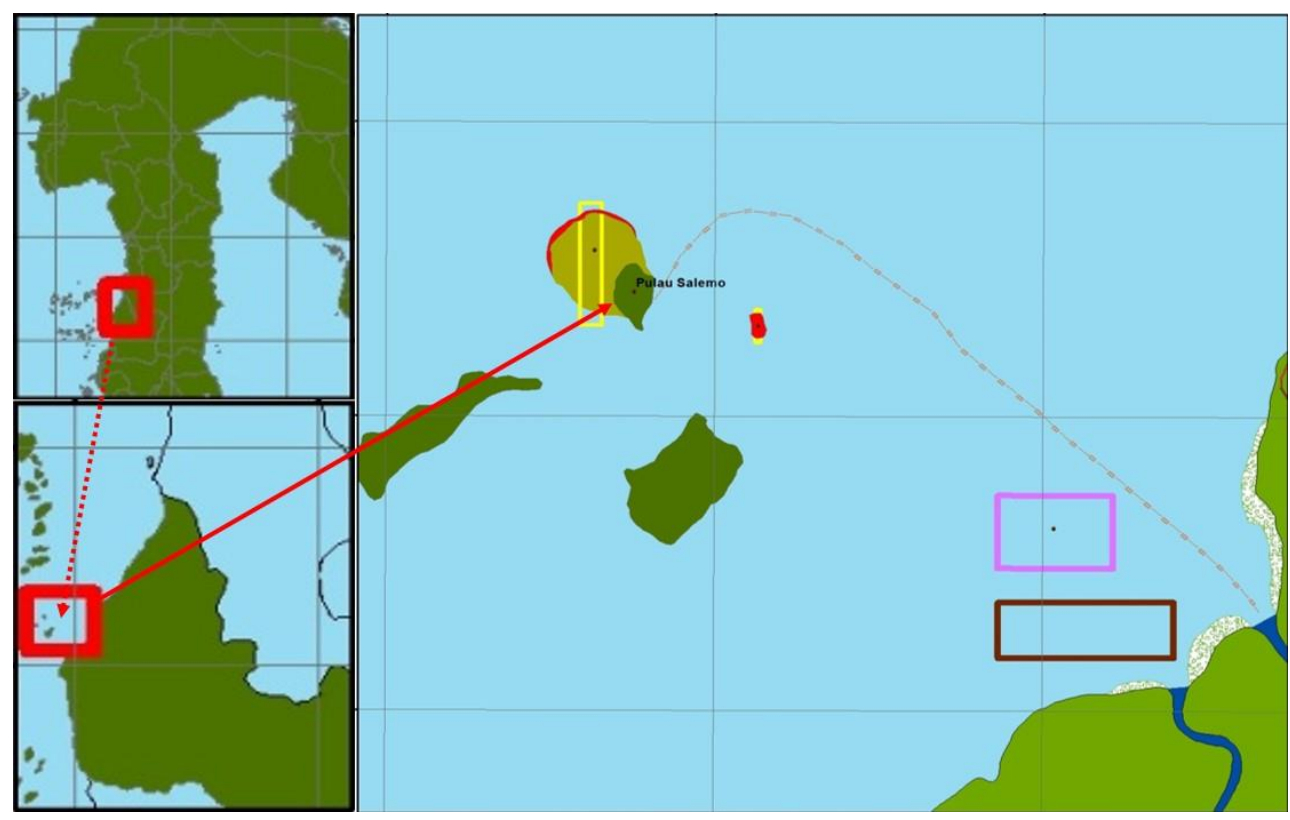

Figure 1. Study area 
Procedures. Data collected are primary data (relative abundance) and environmental factors. The specimens of the blue swimming crab were observed in each habitat based on the number of catches. Catches and fishing efforts are counted in units of weight $(\mathrm{kg})$ and units of the trip, respectively. One trip is equaled to 17 hours of fishing activity counting when the operation of fishing gear at 16.00 in the afternoon and the lift-up of fishing gear at $09.00 \mathrm{am}$. Environmental samples such as salinity, dissolved oxygen, ammonia, and nitrates were collected in the field by using a sample bottle and then stored in a cool box and transported to the laboratory for measurement. The current speed was measured with a current meter (kite current) and seawater temperature with a thermometer. Plankton collection was performed with a plankton net (mesh size $25 \mu \mathrm{m}$ and diameter $70 \mathrm{~cm}$ ) that have equipped with a container. It was conducted by putting the plankton net horizontally from the boat to the water and then pulled up gradually. All samples then stored in bottle samples that had been refilled with formalin. Then, it separated and identified at the laboratory using a microscope. Quantitative calculation of plankton was performed using Sedgwik-Rafter Counting Cell. Plankton identification was identified with a book of plankton identification (Newell and Newell, 1965; Sumich, 1999). To analyze the environmental parameters, we measured: dissolved oxygen, temperature, salinity, ammonia, nitrate, plankton, Chlorophyll-a, and current speed (Table 1).

Table 1. Environmental Parameters

\begin{tabular}{cll}
\hline No & Observed parameters & Methods/Tools \\
\hline 1 & Dissolved oxygen $(\mathrm{ppm})$ & DO meter \\
2 & Temperature $\left({ }^{\circ} \mathrm{C}\right)$ & Thermometer \\
3 & Salinity $(\mathrm{ppm})$ & Hand-refractometer \\
4 & Ammonia $(\mathrm{ppm})$ & Spectrophotometer \\
5 & Nitrate $(\mathrm{ppm})$ & Spectrophotometer \\
6 & Plankton & Sedgewick rafter counting \\
7 & Chlorophyll-a & Spectrophotometer \\
8 & Current speed & Current meter (current kite) \\
\hline
\end{tabular}

Data analysis. Capture data and daily fishing effort during the five months of fishing season at each ecosystem are used to calculate catch per unit effort $\left(\mathrm{kg} \mathrm{trip}^{-1}\right)$. Catches per effort was used as variable index of relative abundance (Laevatsu and Hela, 1988). Abundance comparison of the blue swimming crab at each ecosystem was performed by One Way ANOVA test, if there are significant differences, the test will be continued with a Duncan's test. The relationship between blue swimming crab abundance with environmental parameters was analyzed by multiple regression. One Way ANOVA test and multiple regression were analyzed with a SPSS 16.

\section{RESULTS AND DISCUSSION}

Abundance. The results showed that the relative abundance of blue swimming crab that caught at a mangrove in March is $0.03 \mathrm{~kg} \mathrm{trip}^{-1}$, increase in April $0.06 \mathrm{~kg} \mathrm{trip}^{-1}$, and decline in May and June $0.04 \mathrm{~kg} \mathrm{trip}^{-1}$ and then decrease $0.02 \mathrm{~kg}$ trip $^{-1}$ in July. Relative abundance fluctuation of the blue swimming crab also occurred in seagrass. The relative abundance in March is $0.06 \mathrm{~kg} \mathrm{trip}^{-1}$, decline $0.03 \mathrm{~kg} \mathrm{trip}^{-1}$ in April then increase $0.06 \mathrm{~kg}^{-1}$ trip $^{-1}$ in May, June and July. In contrast, the blue swimming crab in the coral reef is increasing in relative abundance in march $0.08 \mathrm{~kg} \mathrm{trip}^{-1}$, the peak is in April with $0.09 \mathrm{~kg} \mathrm{trip}^{-1}$, then decline gradually in May $0.06 \mathrm{~kg} \mathrm{trip}^{-1}$ and increase in June and July are $0.08 \mathrm{~kg} \mathrm{trip}^{-1}$ (Figure 2). 


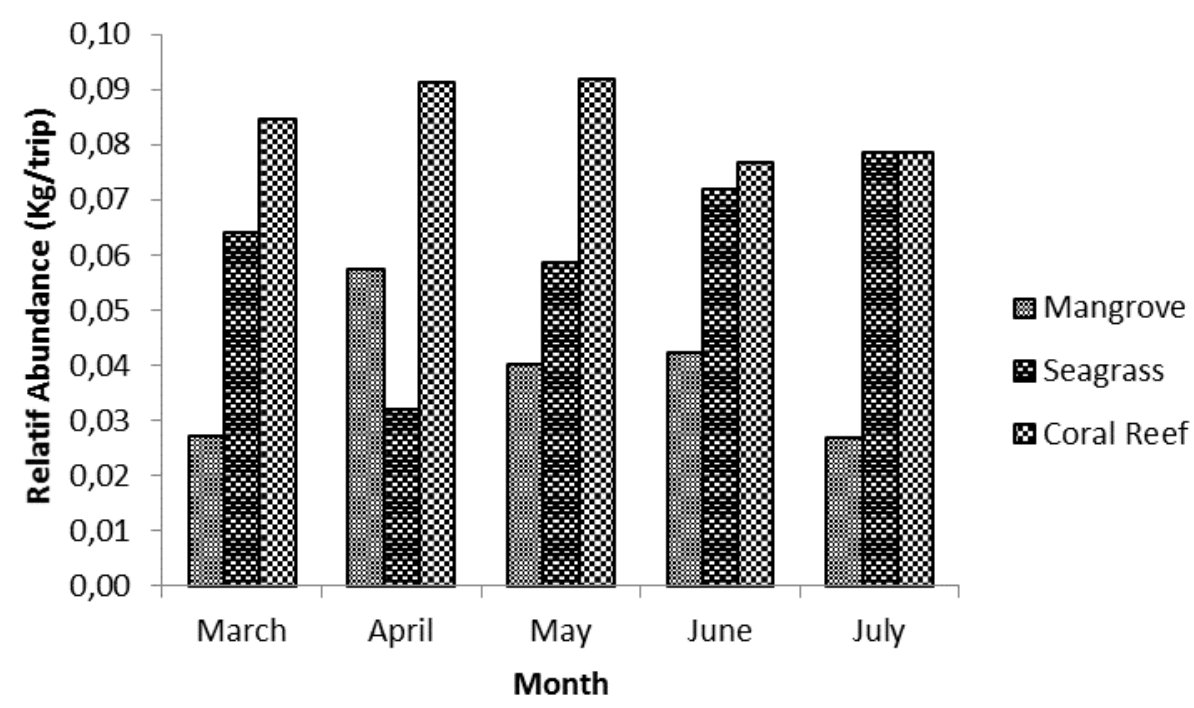

Figure 2. The relative abundance of blue swimming crab that has caught at mangrove, seagrass, and coral reef

The analysis result by One Way ANOVA showed a significant difference in relative abundance for the blue swimming crab that caught in the mangrove, seagrass, and coral reef $(p<0.05)$. However, Duncan test showed that there is no significant difference for the blue swimming crab that caught in mangrove and seagrass. However, the variations of relative abundance are substantial for the crab parent caught in the coral reef, mangrove, and seagrass.

The distribution of catch per unit effort during five months have figured about the relative abundance of the blue swimming crab. A caught blue swimming crab in the mangrove ecosystem increases in April. The plenty of the blue swimming crab in seagrass does not vary, except in April. Moreover, in the coral reef, the blue swimming crab is increased in April. Fluctuations in the relative abundance of the blue swimming crab may be caused due to the biological nature and the changes in the number of catch effort. Changes in marine environment factors also affect the catch per unit effort and may also limit the fishing operations.

Nevertheless, fishers may can in operation for sailing in bad weather. The catch remains low because the abundance of the blue swimming crab is also decreased. According to Sumiono et al. (2010), if the weather is bad, many blue swimming crabs that swim in the middle layer of seawater, and the surface will swim to the bottom of the waters. Besides environmental factor and biological strait, the availability of the blue swimming crab seeds also affects the abundance of the broodstock.

Basically, the blue swimming crab around the mangrove or estuary habitats is very abundant because this area is a nursery and feeding ground habitat (Nurdin, 2015). However, due to the higher intensity of capture in the mangrove ecosystem, the abundance is very low among other ecosystems. Very few the fishers catch the blue swimming crabs in the seagrass and coral reef ecosystems, the fishermen that usually catch at both sites are fishers that operate a gill net. A majority of fishing gear used by fishers in the mangrove ecosystem is bubu, while in the seagrass and coral reef ecosystem is gill net. On one trip, the fishermen usually use 400-600 units of bubu while the gill nets that operated ca.1000-1500 m in length.

The gill net is not productive if it viewed from the aspect of capture; in one trip, the fishermen were only able to catch $1 \mathrm{~kg}$. Compare to the catch of fishers who used the traps able to catch 2$6 \mathrm{~kg}$. However, the operating costs for traps were also relatively high compared to the gill nets. When gill net operated, the costs are only in the gasoline of boats, while the bubu is doubled in the payment of bait because it uses fresh fish such as bete-bete fish (Leioghnatus equulus). The blue swimming crab caught with gill nets is bigger in size than the crab that caught with bubu. 
This is due to the mesh size used in the gill net is large \pm 4 inches or above $10 \mathrm{~cm}$ than bubu traps.

Environmental parameters. The Environmental parameters observed during the study are temperature, salinity, chlorophyll-a, dissolved oxygen, ammonia, nitrate, plankton, and current speed (Table 2).

Table 2. The results of the measurement of environmental parameters on Salemo Island

\begin{tabular}{llll}
\hline Variable & Mangrove & Seagrass & Coral reef \\
\hline Temperature $\left({ }^{\circ} \mathrm{C}\right)$ & $29-30$ & $30-32$ & $30-32$ \\
Salinity $(\mathrm{ppt})$ & $26.0-30.0$ & $30.0-33.9$ & $30.0-35.6$ \\
Chlorophyll-a $\left(\mathrm{mg} . \mathrm{m}^{-3}\right)$ & $0.01-0.11$ & $0.01-0.07$ & $0.01-0.11$ \\
Dissolved Oxygen (ppm) & $4.2-7.9$ & $1.4-7.3$ & $4.6-16.5$ \\
Ammonia (ppm) & $0.002-0.012$ & $0.002-0.003$ & $0.002-0.009$ \\
Nitrate (ppm) & $0.106-0.479$ & $0.097-0.312$ & $0.154-0.308$ \\
Plankton (ind. $\left.\mathrm{L}^{-1}\right)$ & $12,173-546,355$ & $21,231-263,270$ & $6,228-302,902$ \\
Current speed $\left({\left.\mathrm{m} . \mathrm{s}^{-1}\right)}^{0.019-0.087}\right.$ & $0.047-0.078$ & $0.028-0.092$ \\
\hline
\end{tabular}

The results showed that the water temperature in the Salemo Island Spermonde Archipelago 29$32{ }^{\circ} \mathrm{C}$. According to Suharyanto (2011), the optimal range of seawater temperature for blue swimming crab life on Salemo Island is 28.5-31.5 ${ }^{\circ} \mathrm{C}$. The development of ovaries and eggs in the blue swimming crab is strongly controlled by temperature. Even water temperature was being the only factor that can influence the life cycle and the change of population structure for a long period (De Lestang et al., 2003; De Lestang et al., 2010). Also, the temperature of the blue swimming crab can growth is $25-32^{\circ} \mathrm{C}$ (Romano \& Zeng, 2008).

The average salinity in mangrove or estuary ecosystems is $28 \mathrm{ppt}$ lower than the seagrass ecosystem 31.95 ppt and coral reefs 32.8 ppt. Chande and Mgaya (2003) reported that the blue swimming crab could tolerate a salinity at range 9-39 ppt. However, the great range of salinity for the blue swimming crab growth is 26-35 ppt (Romano \& Zeng, 2008). The Female blue swimming crab in the waters of Western Australia that have spawned returning to the estuary but moved again in the winter because the salinity was lower (Kangas, 2000). Salinity was a major environmental factor that increases survival rates from the larval stage to adulthood (Romano \& Zeng, 2006; Nitiratsuwan et al., 2010).

Chlorophyll-a concentration is one of the parameters that greatly determine the primary productivity in the sea (Rasyid \& Ibrahim, 2013). The average of chlorophyll-a concentrations based on research results in the mangrove, seagrass, and coral reef ecosystems were $0.06 \mathrm{mg}$. $\mathrm{m}^{-3}, 0.04 \mathrm{mg} . \mathrm{m}^{-3}$, and $0.06 \mathrm{mg} . \mathrm{m}^{-3}$, respectively. According to Schmittou (1991), the dissolved oxygen content of $2 \mathrm{ppm}$ still shows safe for aquatic organisms. Moreover, the organism will be stressed if the dissolved oxygen content is under $2 \mathrm{ppm}$.

The results showed that the average levels of ammonia and nitrate in the mangrove ecosystem were $0.007 \mathrm{ppm}$ and $0.292 \mathrm{ppm}$, seagrass $0.003 \mathrm{ppm}$, and $0.205 \mathrm{ppm}$, and coral reef $0.006 \mathrm{ppm}$ and $0.231 \mathrm{ppm}$, respectively. The blue swimming crab has a high tolerance to ammonia and nitrates (Romano \& Zeng, 2008). The average abundance of plankton in the mangrove ecosystem is 279,264 ind. $\mathrm{L}^{-1}$ higher than in the seagrass ecosystem 142,251 ind. $\mathrm{L}^{-1}$ and coral reefs 154,565 ind. $\mathrm{L}^{-1}$. Average current velocity in mangrove ecosystems is $0.053 \mathrm{~m}^{-1} \mathrm{~s}^{-1}$,

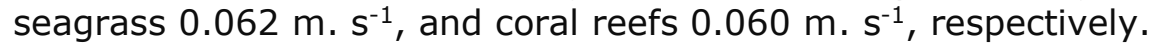


The results of multiple regression analysis (enter method) on any environmental parameters that estimated to have an influence on the relative abundance of blue swimming crabs can be described with this equation:

$Y=-0,133-2,076 X_{1}+0,039 X_{2}+0.000 X_{3}+0,006 X_{4}-0,075 X_{5}-0,199 X_{6}-3,135 X_{7}-0,000 X_{8}$ $\mathrm{R}^{2}=0,70$

Note: $Y$ is relative abundance, $X_{1}$ is ammonia, $X_{2}$ is a nitrate, $X_{3}$ is dissolved oxygen, $X_{4}$ is salinity, $X_{5}$ is chlorophyll- $a_{1} X_{6}$ is current speed, $X_{7}$ is plankton, and $X_{8}$ is temperature.

The coefficient of determination $\left(R^{2}\right)$ between the relative abundance of the blue swimming crab with environmental parameters observed is 0.70 . It explains that the environmental parameters measured in this study contributed $70 \%$ to the relative abundance of the blue swimming crab. Environmental parameters that significantly influence the abundance of blue swimming crab is salinity ( $p<0.05$ ). According to Dineshbabu et al. (2008), salinity is closely related to the abundance of the broodstock. The broodstock will migrate to avoid the low salinity condition (Potter and De Lestang, 2000). This is very closely related to the reproductive behavior of the blue swimming crabs that seek a higher salinity for spawning purposes (Potter \& De Lestang, 2000; Anna et al., 2012).

\section{CONCLUSION}

Blue swimming crab is abundant in both seagrass areas and coral reefs. Environmental parameters contribute $70 \%$ to relative abundance. The environmental parameter that significantly affected the abundance of the broodstock is salinity. A prohibited area that proper for blue swimming crabs are seagrass and coral reefs ecosystem.

\section{ACKNOWLEDGMENTS}

This paper is a contribution of the research activity results in determining the No Take Zone of blue swimming crab in Salemo Island. The research was carried out over the financing of BPPDN DIKTI.

\section{REFERENCES}

Adam, Firman, \& Anwar. (2016). Crab fisheries management model to increase fishermen income's in Pangkep Regency [Indonesian]. Jurnal Galung Tropika, 5(3), 203-209. http://dx.doi.org/10.31850/jgt.v5i3.190

Anna, S., Turra, A., \& Zarra, F. (2012). Reproductive migration and population dynamics of the blue swimming crab Callinectes danae in an estuary in southeastern Brazil. Marine Biology Resources, 8(4), 354-362. https://doi.org/10.1080/17451000.2011.637563

Chande, A. I., \& Mgaya, Y. D. (2003). The Fishery of Portunus pelagicus and species diversity of portunid crabs along the Coast of Dar es Salaam, Tanzania. Western Indian Ocean Journal Marine Science, 2(1), 75-84. https://doi.org/10.4314/wiojms.v2i1.28431

De Lestang, S., Hall, N. G., \& Potter, I. C. (2003). Do the age compositions and growth of the crab Portunus pelagiaus in Marine Embrayments and Estuaries Differ?. Joumal of the Marine Biological Association of the United Kingdom, 83, 971-978. https://doi.org/10.1017/S0025315403008166h

De Lestang, S., Bellchambers, L. M., Caputi, N., Thomson, A. W., Pember, M. B., Johnston, D. J., \& Harris, D. C. (2010). Stock-recruitment-environment relationship in a Portunus pelagicus fishery in Western Australia. Biology and Management of Crabs under Climate Change, 317334.

Dineshbabu, A. P., Shridhara, B., \& Muniyappa, Y. (2008). Biology and exploitation of the blue swimmer crab, Portunus pelagicus (Linnaeus, 1758), from South Karnataka Coast, India. Indian Journal of Fisheries, 55(3), 215-220. http://eprints.cmfri.org.in/id/eprint/106 
Ernawati, T., Boer, M., \& Yonvitner. (2014). Population biology of blue swimming crab (Portunus pelagicus) in surrounding Pati Waters, Central Java [Indonesian]. Bawal, 6(1), 31-40. http://dx.doi.org/10.15578/bawal.6.1.2014.31-40

Fudjaja, L., Didi, R., Radi, A. G., Jamaluddin, J., \& Heliawaty. (2013). Multistakeholder access in blue swimming crab management system (Portunus pelagicus Linn.) in Barru Regency. Presented in national seminars relating to the application of the system and the complexity of national agribusiness development. Jatinangor.

Kangas, M. I. (2000). Synopsis of the biology and exploitation of the blue swimmer crab, Portunus pelagicus Linnaeus, in Western Australia. Fisheries Research Report.

Kusuma, B. T., \& Dewi, D. M. (2017). The role of policies and fisheries institutions in the management of blue swimming crab (Portunus pelagicus) to reach sustainable fisheries [Indonesian]. National Proceedings Symposium on Crustaceans in 2017.

Laevatsu, T. \& Hela, A. L. (1981). Marine fisheries ecosystem, its quantitative evaluation and management. London: Fishing News Books.

Newell, G. E. \& Newell, R. C. (1965). Marine Plankton a Practical Guide. Hutchinson of London.

Nitiratsuwan, T., Nitithamyong, C., Chiayvareesajja, S., \& Somboonsuke, B. (2010). Distribution of blue swimming crab (Portunus pelagicus Linnaeus, 1758) in Trang Province. Songklanakarin Journal of Science and Technology, 32(3), 207-212.

Nurdin, M. S. (2015). Blue swimming crab no take zone in Salemo Island Pangkajene Kepulauan Regency [Indonesian] (Master's thesis. Hasanuddin University, Makassar, Indonesia)

Nurdin, M. S., Ali, S. A., \& Yanuarita, D. (2015). Mortality and Exploitation rate of the blue swimming crab (Portunus pelagicus) Salemo Island Waters Pangkajene Kepulauan Regency [Indonesian]. Jurnal Ipteks PSP, 2(4), 316-321. http://dx.doi.org/10.20956/jipsp.v2i4.1901

Nurdin, M. S., Ali, S. A., \& Satari, D.Y. (2016). Sex Ratio and Size At First Maturity Of Blue swimming crab (Portunus pelagicus) at Salemo Island, South Sulawesi. Ilmu Kelautan, 21(1), 17-22. http://dx.doi.org/10.14710/ik.ijms.21.1.17-22.

Nurdin, M. S., \& Haser, T. F. (2018). Condition coefficient of the blue swimming crab (Portunus pelagicus) Catched in Mangrove, Seagrass And Coral Reef Ecosystem in Salemo Island, South Sulawesi [Indonesian]. Jurnal Ilmiah Samudra Akuatika, 2(1), 9-13. http://jurnal.unsam.ac.id/index.php/jisa/article/view/666

Nurdin, M. S., Hasanah, N., \& Putra, A. E. (2019a). Recruitment pattern of blue swimming crab portunus pelagicus in Salemo Island waters, South Sulawesi Province [Indonesian]. Jurnal Agrisains, 20(1), 1-6.

Nurdin, M. S., Haser, T. F., Azmi, F., \& Hasanah, N. (2019b). Fishery management strategy based on spatial and temporal distribution study of berried female size in blue swimming crabs [Indonesian]. Jurnal IImiah Samudra Akuatika, 3(2), 14-20.

Panggabean, A. S., Pane, A. R. P., \& Hasanah, A. (2018). Population dynamics and utilization level of blue swimming crab (Portunus pelagicus Linnaeus,1758) in Jakarta Bay Waters [Indonesian]. Jurnal Penelitian Perikanan Indonesia, 24(1), 73-85. http://dx.doi.org/10.15578/jppi.1.1.2018.73-85

Potter, I. C., \& de Lestang, S. (2000). Biology of the blue swimmer crab Portunus pelagicus in Leschenault Estuary and Koombana Bay, South-Western Australia. Journal of the Royal Society of Western Australia, 83, 443-458. https://researchrepository.murdoch.edu.au/id/eprint/17431/

Rasyid, A. J., \& Ibrahim. (2013). Oceanography condition of Spermonde versus pelagic fish [Indonesian]. Makassar: Masagena Press.

Romano, N., \& Zeng, C. (2006). The effects of salinity on the survival, growth, and hemolymph osmolality of early juvenile blue swimmer crab, Portunus pelagicus. Aquaculture, 260: 151162. https://doi.org/10.1016/j.aquaculture.2006.06.019

Romano, N., \& Zeng, C. (2008). Blue swimmer crabs emerging species in Asia. Global Aquaculture Advocate. https://researchonline.jcu.edu.au/28576/

Schimittou, H. R. (1991). Cage cultivation: a fish production method in Indonesia [Indonesian]. Jakarta: FRDP Puslitbang Perikanan.

Siang, R. D., \& Nurdiana, A. (2015). Cost structure and profitability of the miniplant business of swimming crab (Portunus pelagicus) [Indonesian]. Jurnal Bisnis Perikanan, 2(1), 91-100. http://ojs.uho.ac.id/index.php/bisnisperikanan/article/view/517 
Suharyanto. (2011). The season and seed density of the blue swimming crab (Portunus pelagicus) at the waters of Salemo Island, South Sulawesi [Indonesian]. Nasional conference VII.

Sumich, J. L. (1999). An introduction to the biology of marine life $7^{\text {th }}$ ed. Grossmont College. WCB/McGraw-HillCompanies. USA.

Sumiono, B., Mahiswara., \& Suprapto. (2010). Study of blue swimming crab resources (stock assesment, fishing technology, and water environment) in Cirebon Waters. Balai Riset Perikanan Laut Kementerian Kelautan dan Perikanan. 